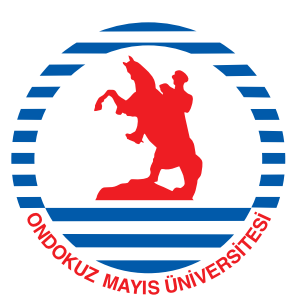

Journal of Experimental and Clinical Medicine Deneysel ve Klinik Tip Dergisi

Klinik Araştırma / Clinical Research

doi: $10.5835 /$ jecm.omu.29.02.011

\title{
Acil serviste beyin damar hastalığı tanısı alan hastaların geriye dönük incelenmesi
}

\author{
Celal Katı*a, Hızır Ufuk Akdemir ${ }^{a}$, Dursun Aygün ${ }^{\mathrm{b}}$ \\ a Ondokuz Mayıs Üniversitesi Tıp Fakültesi, Acil Tıp Anabilim Dall, Samsun, Türkiye \\ ${ }^{b}$ Ondokuz Mayıs Üniversitesi Tıp Fakültesi, Nöroloji Anabilim Dalı, Samsun, Türkiye
}

A retrospective analysis of patients with a diagnosis of cerebrovascular disease in the emergency department

\begin{tabular}{|c|c|}
\hline \multicolumn{2}{|c|}{ MAKALE BİLGILERİ } \\
\hline \multicolumn{2}{|c|}{ Makale geçmişi } \\
\hline Geliş tarihi & $: 06 / 02 / 2012$ \\
\hline Kabul tarihi & : 12 / $02 / 2012$ \\
\hline
\end{tabular}

\author{
* Yazışma Adresi: \\ Celal Katı \\ Ondokuz Mayıs Üniversitesi Tıp Fakültesi, \\ Acil Tip Anabilim Dalı, \\ Samsun, Türkiye \\ e- posta: celal.kati@omu.edu.tr
}

\section{Anahtar Kelimeler:}

Akut beyin damar hastalıkları

Acil servis

Retrospektif çalışma

Siklık

Risk faktörleri

Sinıflandırma

\section{Keywords:}

Acute cerebrovascular diseases

Emergency service

Retrospective study

Frequency

Risk factors

Classification

\section{ÖZET}

Beyin damar hastalıkları (BDH), beyin damarlarının primer patolojileri ile ilişkili olarak asemptomatik veya beynin bir bölgesinin geçici veya kalıcı olarak, iskemi veya kanama nedeniyle etkilenmesine bağlı gelişen klinik tablolardır. Bu çalışmada akut BDH tanısı alan hastaların verilerinin retrospektif olarak incelenmesi, böylelikle akut BDH'lı olguların acil servise (AS) getirilme zamanları, AS'te kalış süreleri ve AS sonrası durumlarının belirlenmesi, akut BDH alt tiplerinin sıklığının ortaya konulması amaçlandı. Çalışma, Eylül 2001-Ocak 2004 tarihleri arasında başvuran 911 akut BDH'lı hastanın klinik kayıtları üzerinden yapıldı. Olguların demografik özellikleri, başvuru şikayetleri, risk faktörleri, mental durumu, vital bulguları, AS'e varış ve gözlem süreleri, rutin laboratuvar tetkikleri ve radyolojik tetkik sonuçları incelendi. Hastalar; 45 yaş altı, 45-65 yaş arası ve 65 yaş üstü gruplara ayrıldı. Akut BDH tüm acil başvurularının \% 4,4'ünü oluşturdu. Hastaların \% 42,0'sinde iskemik inme (III), \% 30,0'unda spontan intraserebral hemoraji (SİH), \% 27,0'sinde subaraknoid kanama (SAK) ve \% 1,0'inde geçici iskemik atak (GİA) mevcut idi. Olguların \% 65, 1 'inde hipertansiyon vardı. Hipertansiyon, kalp hastalıkları (\% 21,7), geçirilmiş inme öyküsü (\% 21,7), atrial fibrilasyon (AF) (\% 18,2), diabetes mellitus $(\% 14,9)$ ve sigara $(\% 13,0)$ içimi izledi. Tüm hastaların \% 3,6'sında inme aile öyküsü mevcut idi. Elektrokardiyografide AF, İ''li hastaların \% 37,5'inde saptand. Hastaların $\%$ 70,0'inde hiperglisemi ve \% 26,7'sinde hiponatremi tespit edildi. Hiponatremi sıklı̆̆ SAK grubunda (\% 30,7) daha yüksekti. İ' li hastaların \% 20,7'si ilk 3 saatte, \% 38,5'i 3-6 saatte ve \% 40,8'i 6 saatten sonra AS'e başvurmuş olup, evden gelen III'li hastaların ilk üç saatte başvuru oranları \% 48,7 iken hastaneden gelen hastaların ilk üç saat içerisinde başvurma oranları \% 20,7 idi. Sonuçlarımız daha önceki çalıșmalarla büyük paralellikler göstermekle birlikte en önemli sorun trombolitik tedavi için altın pencere dönemi olan ilk üç saat içinde merkezimize ulaştırılan hasta oranının düşük olmasıdır.

J. Exp. Clin. Med., 2012; 29:135-140

\section{ABSTRACT}

Cerebrovascular diseases (CVD) are clinical pictures, in association with the primary lesions of the brain's vessels, without symptoms or, involving transient or persistent ischemia or hemorrhage in a brain region. Our aim is to assess the data of the patients who were diagnosed as acute CVD in the emergency service (ES), including the arrival and observation times of the patients in the ES, and determining the frequency of the subtypes of acute CVDs retrospectively. The study included 911 patients from September 2001 to January 2004. The data of the study are consist of the demographic characteristics, complaints on admission, risk factors, mental status, vital findings, the arrive and observation times in the ES, routine laboratory examination, and radiologic measures of the cases, obtained from the case notes. The patients were subdivided into three groups as under 45 years old, between 45-65 years old, and over 65 years old. The cases with CVD constituted $4.4 \%$ of all emergency service patients. Of the cases, $42 \%$ had ischemic stroke (IS), 30.0\% had intracerebral hemorrhage (ICH), 27.0\% had subarachnoid hemorrhage (SAH), and $1.0 \%$ had transient ischemic attack (TIA). Of the patients, $65.1 \%$ had a history of hypertension, which was significantly more frequent, compaired to other risk factors. In the patients history, other risk factors included cardiac 
diseases $(21.7 \%)$, stroke $(21.7 \%)$, atrial fibrillation (18.2\%), diabetes mellitus (14.9\%), and smoking $(13.0 \%)$. There was a family history of stroke in $3.6 \%$ of all patients. Atrial fibrilation $(37.5 \%)$, which was obtained on admission, was significantly more frequent in IS than other subtypes of CVD. In $70.0 \%$ of the patients, hyperglycemia was established. Hyponatremia, which was established in $26.7 \%$ of the patients, was more frequent in SAH. Of these patients, 20.7\% arrived at ES within the first 3 hours; however $38.5 \%$ of the patients arrived at from 3 to 6 hours, and $40,8 \%$ of the patients arrived within at the 6 hours. The ratio of the patients with IS $(48.7 \%)$ who came from home first three hours was significantly more frequent than the patients who were referred from a hospital $(20.7 \%)$. Although most of our results resemble to those in the literature the most important problem is the low ratio of the patients who arrived our hospital within the first three hours.

\section{Giris}

İnme, koroner kalp hastalıkları ve kanserden sonra ölüm nedenleri arasında üçüncü sırada yer almaktadır (WHO, 1999; Biler ve ark., 2004; Çoban, 2004). Sakatlık/özürlülük yapma sıklığı açısından ise birinci sırada gelmektedir. İnmeyle ilgili bu ağır mortalite ve morbidite oranlarını azaltmak için inme risk faktörlerinin düzeltilmesi kadar inme geçiren hastanın çok kısa sürede ilgili bir merkeze ulaştırılması da önemlidir. Akut beyin damar hastalıkları (BDH) hastaların ilk değerlendirildikleri klinikler acil servislerdir. Akut BDH ile ilgili acil servis (AS) verilerinin dökümantasyonu bu hastaların tanı-tedavi stratejilerini belirlemede yol gösterici olabilir. İnme tiplerinin oranlarının sağlıklı belirlenmesi oldukça zordur. Türkiye'de inme prevalansı veya insidansına ait sağlıklı veriler yoktur. Bugün için epidemiyolojik bilgilerimiz batı kaynaklarından gelmektedir. Bu çalışmada, Ondokuz Mayıs Üniversitesi (OMÜ) Tıp Fakültesi Acil Tıp Anabilim Dalı'na akut inme tanısı ile başvuran hastaların verileri retrospektif olarak incelenmiştir. Olguların acile getirilme zamanları, AS'te kalış süreleri ve AS sonrası durumları, inme alt tipleri değerlendirilmiştir.

\section{Gereç ve yöntem}

$\mathrm{Bu}$ retrospektif çalışma, hastanemiz Acil Tıp A.D.'na Eylül 2001-Ocak 2004 tarihleri arasında başvuran akut inme tanısı alan 911 erişkin hastayı kapsamaktadır. Üniversitemiz etik kurulundan izin alındıktan sonra çalışma başlatılmıştır. Çalışmaya dahil etme kriterleri; 1-Çalışma protokolünde yer alan verileri karşılama, 2-İnmenin ilk 48 saatinde başvurmuş olmak, 3-Hastanın 18 yaş üzerinde olması

Her bir hastanın kendisinden veya yakınından ayrıntılı öykü alındı. Öyküde şunlar sorgulandı: Hastalığın oluş zamanı, seyri, bilinç kaybı olup olmadığı, olmuşsa ani mi yavaş mı geliştiği, kasılma, idrar kaçırma, ağızdan köpük gelme, baş ağrısı, baş dönmesi, bulantı veya kusma, taraf güçsüzlüğü, görme bozukluğu olup olmadığı, semptomların başladığı dönemde aktivite durumu. Özgeçmişinde, inme ve geçici iskemik atak (GİA) öyküsü, hipertansiyon, kalp hastalığı, diabetes mellitus, böbrek yetmezliği, epilepsi gibi hastalıkların varlığı ve kronik ilaç kullanımı sorgulandı. Hastaların detaylı fizik muayenesi ve nörolojik muayenesi yapıldı. Hastalar anamnez, nörolojik muayene, nörogörüntüleme (beyin tomografisi veya manyetik rezonans görüntüleme) ve lomber ponksiyon (LP) sonuçlarına göre dört gruba ayrıldı: 1-Subaraknoid kanama, 2-İntraserebral kanama, 3-İskemik inme, 4-Geçici iskemik atak.
İskemik inme tanısı alan hastalar arter sulama alanlarına göre; 1-Orta serebral arter, 2- Anterior serebral arter, 3-Lentikülostriat arter, 4-Posterior serebral arter, 5-Superior serebellar arter, 6-Anterior inferior serebellar arter, 7-Posterior inferior serebellar arter, 8-Laküner olarak sinıflandirıld1.

Intraserebral kanamalar nörogörüntüleme lokalizasyona göre; 1-Bazal ganglion, 2-Talamik, 3-Lober, 4-Serebellar, 5-Beyin sapı, olarak sinıflandırıldı.

BDH alt tipleri cinsiyet ve yaş açısından mukayese edildi. Yaş; 45 yaş ve altı, 45-65 yaş arası ve 65 yaş üstü olarak 3 alt tipe ayrıldı. Aynı zamanda yaş grupları, BDH alt tipleri ile istatistiksel bakımdan karşılaştırıldı. Hastaların başvuru yakınmaları; bilinç kaybı, taraf güçsüzlüğü, baş ağrısı ve diğer şikayetler (görme bulanıklığı, çift görme, dengesizlik, epileptik nöbet) olarak değerlendirildi. Hastaların başvuru bilinç düzeyleri Glasgow Koma Skalası (GKS) ile belirlendi ve inme alt tipleri arasında istatistiksel olarak anlamlı bir farklılık olup olmadığına bakıldı. Hastaların özgeçmişinde inme risk faktörleri (hipertansiyon, inme, kalp hastalı̆̆ı, aritmi, diabetes mellitus, GİA, sigara, alkol, epilepsi, migren gibi) araştırıldı. Hastaların geliş anındaki arteriyel tansiyonuna bakıld1. Tanı gruplarında hipertansiyon görülme oranı hesapland1. Vücut 1s1s1, hem ortalama değerler hem de hipertermi olarak belirlendi ve BDH alt tipleri bu parametreler açısından karşılaştırıldı.

\section{İstatistiksel çalışmalar}

Hastaların elde edilen verileri SPSS 11.0 (Statistical Package for Social Science) bilgisayar programına yüklendi. Çapraz tablo karşılaştırmasında Ki-Kare testi uygulandı. Gruplar arası karşılaştırmalarda normal dağılıma uyan veriler için, student-t testi, normal dağılım göstermeyen veriler için ise Man-Whitney-U testi uyguland. Varyans analizlerinden sonra, ortalamaların çoklu karşılaştırılması için Tukey ve Banferroni çoklu karşılaştırma testleri uygulaması yapıldı. $\mathrm{p}<0,05$ olan değerler anlamlı kabul edildi.

\section{Bulgular}

Eylül 2001-Ocak 2004 tarihleri arasında akut inme tanıs1 alan 911 hasta çalışmaya alındı. Olguların 378'i (\% 41,5) iskemik inme (İi), 521'i (\% 57,2) hemorajik inme (HI) ve 12'si (\% 1,3) GİA idi. Hemorajik inmeli hastaların \% 53,2'si spontan intraserebral hemoraji (SIH) ve $\% 46,8$ 'i subaraknoid kanama (SAK) idi. Akut inmeli 911 olgunun \% 46,2'si 65 yaşın üzerinde idi. İI tanısı en sık 65 yaş üzerinde görülürken, 


\begin{tabular}{lcccc}
\hline \multicolumn{5}{c}{ Tablo 1. Akut beyin damar hastalıkları alt gruplarının hasta } \\
yaş gruplarına göre dağılımı
\end{tabular}

SAK: subaraknoid kanama; SİH: spontan intraserebral hemoraji; Iİ:iskemik inme; GİA: geçici iskemik atak; *: satır yüzdesi; **: sütun yüzdesi

GİA, SİH ve SAK tanıları da 45-65 yaş grubundaki hastalarda daha sık idi. Akut BDH alt gruplarının hasta yaş gruplarına göre dağılımı Tablo 1'de verilmiş̧tir.

Bilinç kaybı BDH arasında en fazla hasta SïH grubunda görülmekte $(\mathrm{n}=182)$ olup, SAK ve İ̈ gruplarına göre istatistiksel olarak anlamlı bir farkll1ık mevcut idi $(\mathrm{p}<0,05)$. Taraf güçsüzlüğü şikayeti, İi hastalarında daha yüksekti $(\mathrm{n}=149)$ ve SAK ile SïH hasta gruplarına göre istatistiksel olarak anlamlı bir farklılı mevcut idi $(\mathrm{p}<0,05)$. SïH tanısı alan hastalarda da taraf güçsüzlüğü SAK tanısı alan hastalara göre fazla idi ve anlamlı bir farkl11lk mevcut idi $(\mathrm{p}<0,05)$.

Hastaların sadece \% 4,8'inde ( $\mathrm{n}=44)$ epileptik nöbet saptandi. Bunların da \% 59,0'unu SAK tanisı alan hastalar oluşturmaktaydı. SAK'lı hastaların \% 10,6'sında, SİH'lı hastaların \% 2,5'inde, İI'li hastaların \% 2,9'unda epileptik nöbet vardı. Epileptik nöbet geçiren SïH' 11 hastaların $(n=7)$ 2'si beyin sapına, 2'si sağ ve 2'si sol olmak üzere 4'ü pariyetal loba, 1'i de sol bazal gangliona lokalize idi. Epileptik nöbet geçiren 44 hastanın özgeçmişinde epilepsi veya epileptik nöbet geçirme öyküsü olan yalnızca $4(\% 9,1)$ hasta vardı. BDH'nın alt tiplerinde özgeçmişlerindeki risk faktörlerine bakıldığında, SAK tanısı alan hastaların \% 41,8'inde herhangi bir risk faktörü yoktu. SïH ve İI tanısı alan hastalara göre SAK tanısı alan hastalarda özgeçmişinde herhangi bir hastalık olmaması istatistiksel olarak anlamlıydı $(\mathrm{p}<0,05)$.

Tüm inme gruplarında hipertansiyon $(\%$ 65,1) en sık karşılaşılan hastalık olup, bunu kalp hastalıkları (\% $21,7)$, inme (\% 21,7), diabetes mellitus (\% 14,9) ve sigara alı̧̧kanlığı (\% 13) izlemekteydi. Hastaların alkol alışkanlığ $(\% 3,5)$ ise düşük olarak saptandı. SAK tanısı alanlarda da hipertansiyonun (\% 48) yüksek olasılıklı bir risk faktörü olduğu, diğer hastalıkların ise çok düşük oranlarda kaldıkları görüldü. Diğer BDH alt tipleri ile karşılaştırılan SïH' 11 hastalarda hipertansiyon öyküsünün hastaların \% 72,6 gibi büyük çoğunluğunda olması, istatistiksel olarak anlamlı idi $(p<0,05)$. SAK tanısı alan hastaların özgeçmişlerindeki hastalıkların ve alışkanlıkların düşük sayıda olması gerek Iİ, gerekse SïH ile karşılaştırıldığında istatistiksel olarak anlamlı idi $(p<0,05)$. Iİ'li hastalarda geçirilmiş inme, hipertansiyon, diabetes mellitus, kalp hastalığı öyküsü, sigara ve alkol alışkanlığ diğer $\mathrm{BDH}$ alt tiplerine göre anlamlı olarak yüksekti $(\mathrm{p}<0,05)$.

SiH içinde oral antikoagülan kullanan hastaların oranı $\%$ 3,6 idi. Bizim çalışmamızda hematolojik testler 347 hastada bakıldı. INR yüksekliği $(>1,1)$ olan hasta sayısı $40(\% 11,2)$ olup, SïH ve SAK tanı gruplarında 13 'er (\% 11,6; \% 16) Iİ' de ise $14(\% 9,1)$ hastada mevcut idi. Tüm BDH'nda 134 hasta $(\%$ 14,7) antiagregan ilaç kullanmıştı. Bunların \% 26,1'i intraserebral kanama (ISK) grubunda olup, SïH tanı grubundaki hastaların antiagregan kullanım oranı \% 13 idi. BDH'nın alt tiplerinin soy geçmişle ilişkisine bakıldığında ise, tüm hastaların 33'ünde $(\% 3,6)$ ailesinde $\mathrm{BDH}$ öyküsü mevcut idi. Bilinç düzeyi açısından tüm inme gruplarına bakıldığında, GİA tanısı alan hastaların hiçbirinde, İi hastalarının da \% 50,5'inde bilinç bozukluğu saptanmadi. Koma tablosunda olan hastaların çoğunu da SïH tanısı alan hastalar (\% 43,3) oluşturdu. Tüm hasta gruplarına bakıldığında da hastaların \% 59,6'sında bilinç bozukluğu varken, \% 40,4'ünde bilinç düzeyinin normal olduğu tespit edildi. Olguların \% 26, '1'inde koma tablosu bulunmakta idi. Genel olarak bilinçteki bozulma sıklık sırasına göre; SïH $>$ SAK $>$ II olarak sıralandı. BDH'lı olguların hastaneye başvurudaki şikayetleri Tablo 2'de verilmiştir.

Tablo 2. Beyin damar hastalıklı olguların hastaneye başvuru
şikayetleri

SAK: subaraknoid kanama; SİH: spontan intraserebral hemoraji; İi:iskemik inme; GİA: geçici iskemik atak

En düşük ortalama GKS değeri SïH tanısı alan hasta grubunda idi ve bu sonuç diğer hasta gruplarına göre istatistiksel olarak farklı idi $(\mathrm{p}<0,05)$. SAK ve İI tanısı alan hasta gruplarında ise ortalama GKS birbirine yakındı ve anlamlı bir farklılık görülmedi ( $p>0,05)$. Bununla beraber SAK' daki ortalama skor $(11,6)$, İ'’ li hastalardaki ortalama skordan $(12,1)$ daha düşüktü. Hastaların \% 67'sinde hipertansiyon tespit edildi. SïH tanı grubunda acile başvuru ve takibi sırasında hastaların \% 83,8'inde hipertansiyon tespit edildi. $\mathrm{BDH}$ alt gruplarında ateş yüksekliği (aksiler $>37,2^{\circ} \mathrm{C}$ ) olan hastaların sayısına bakıldığında; tüm tanı gruplarında hastaların \% 10,5'inde $(\mathrm{n}=96)$ ateş yüksekliği mevcut idi. Sï' de 34 hastada (\% 12,2), SAK tanısı alanların $29^{\prime}$ unda $(\% 11,9)$ ve III tanı grubunda 33 hastada (\% 9) ateş yüksekliği mevcut olup, GİA tanısı alanlarda ateş yüksekliği saptanmadı. SïH'li hastaların tamamında tanı ilk çekilen bilgisayarlı beyin tomografisi (BBT) ile doğrulanmıştır. SAK tanısı alan 18 hastanın $(\% 7,4)$ ilk çekilen BBT normal olarak değerlendirildi. İI tanısı alan 91 hastanın da $(\% 24,1)$ ilk çekilen BBT' nde herhangi bir bulguya rastlanmayıp, normal olarak değerlendirilmiştir.

Toplam 378 III'li hastanın 287'sinde BBT'nde iskemik infarkt ile uyumlu bulgular vardı. Böylece İI'li olgularda BBT ile lezyon saptama oran $\%$ 75,9 idi. İI tanısı alan hastalarda en sik orta serebral arter (OSA) sulama alanına ait lezyonlar $(\%$ 64,0) saptandi. SïH'li olgularda $(\mathrm{n}=277)$ en sik bazal ganglion lokalizasyonunda kanama görüldü (\% 40). BBT ile değerlendirildikten sonra manyetik rezonans görüntüleme (MRG) çekilen $(\mathrm{n}=53)$ hastaların sonuçlan birbirleri ile 
karşılaştırıldı. BBT'sinde SİH bulguları görülen hastaların MRG sonuçları da aynı idi. Sekiz hastanın BBT'sinnde görülen SAK bulguları MRG ile de doğrulandı. Ancak BBT normal olan 1 hastanın MRG' nde SAK bulguları görüldü. BBT normal olan 2 hastanın MRG bulguları da normal olup Lomber Ponksiyon (LP) neticesinde bu hastalara SAK tanis1 kondu. Normal BBT bulguları olan 23 hastanın MRG' de 16 hastada $(\% 69,6)$ İI, 1 hastada $(\%$ 4,3) SAK saptanırken 6 hastanın $(\%$ 26,1) MRG' si normaldi. İI tanısı alıp BBT ve MRG normal olan 4 hasta vardi.

Hastalara çekilen EKG'deki bulgular bakımından $(n=834)$ tüm inme tipleri karşılaştırıldı. Anormal EKG bulguları en sık İI'li olgular arasında görüldü. Hastaların \% 70'inde normal sinüs ritmi ve \% 18,2'sinde AF tespit edildi. İI'li hastaların $\%$ 37,5'inde atrial fibrilasyon (AF) saptand1 ve bu sonuç diğer inme tiplerine göre anlamlı olarak yüksekti $(p<0,05)$. Hastalardan başvuru sırasında alınan kan örneklerinden yapılan incelemeler sonucunda, tüm $\mathrm{BDH}$ alt gruplarında ortalama glukoz değeri normalden yüksekti. 638 (\% 70) hastada hiperglisemi tespit edilmiş olup, tanı grupları içinde en yüksek oran $(\% 79,1)$ SİH tanısı alanlarda saptandı. Ortalama sodyum değerleri açısından en düşük değerlerin SAK tanısı alanlarda saptanmasına karşın gruplar arasında karşılaştırma yapıldığında istatistiksel olarak anlamlı farklılıklara rastlanılmadi $(\mathrm{p}>0,05)$.

İ́'li 378 olgudan hastanemize getiriliş yeri ve varış süreleri ile ilgili kayıtlarına ulaşılabilen 358 olgunun sonuçları Tablo 3'de gösterilmiştir. $\mathrm{Bu}$ olguların acile getirilme yerleri incelendiğinde hastaların \% 89,7'si ( $\mathrm{n}=321)$ diğer hastanelerden, \% 11,3'ü $(n=37)$ ise evden servisimize getirilmiştir. Olguların \% 20,7'si ( $\mathrm{n}=74)$ ilk 3 saatte getirilirken, $\% 38,5^{\prime} i(n=138) 3$ ile 6 saat içinde ve \% 40,8'i $(n=146)$ de 6 saatten daha uzun bir sürede acilimize getirilmiştir. Evden getirilenlerin \% 48,7'sine $(n=18)$ karşılık diğer hastanelerden getirilen hastaların \% 17,4'ü $(n=56)$ ilk 3 saatte acilimize ulaşmıştır $(\mathrm{p}<0,05)$. Hastanelerden getirilen olguların çoğu $(\% 41,8 ; n=134) 6$ saatten sonra acile getirilmiştir.

\begin{tabular}{lcccc}
\multicolumn{5}{c}{ Tablo 3. İskemik inme tanıs1 alan hastaların hastaneye başvuru } \\
süresi ve geldiği yer
\end{tabular}

\section{Tartışma}

Nörolojik hastalıklar nedeniyle hastaneye yatan olguların yarısını inmeli hastalar oluşturmakta ve 2/3 kadarının ilk değerlendirmesi AS'lerde yapılmaktadır (Altıntop ve ark., 2001). Çalışmamızda BDH'lı olguların \% 57,2'si hemorajik inme, \% 41,5'i İI ve \% 1,3'ü GİA idi. Bu sonuçlar literatürde bildirilenlerden farklıdır. Bogousslavsky ve ark. (1988) İsviçre'de Lozan Bölgesi'nin Nöroloji Kliniği’nde takip edilen olguları inme alt gruplarına göre sınıflandırmışlardır. Buna göre, tüm inmelerin \% 89'unu İİ ve \% 11'ini hemorajik inmeler oluşturmaktadır. Amerika ve Batı Avrupa toplumunda inmeli hastaların \% 85 kadarı iskemi, \% 15 kadarı ise hemoraji tipinde olduğu ve hemorajik inme alt tiplerinden SïH'nin \%
10 ve SAK'nın \% 5 oranında görülebildiği bildirilmektedir (Biler ve ark., 2004). Türkiye'nin Ege Bölgesi'nde yapılan bir çalışmada İI \% 77, hemorajik inme \% 23 olarak bildirilmiştir (Kumral ve ark., 1998). Yazarlar hemorajik inmenin ülkemizde biraz daha fazla görülmesini, hipertansiyonun ve yaşam koşullarının daha kontrolsüz olması ile açıklamaktadır. Bizim çalışmamızda hemorajik inme oranının bu denli yüksek olmasının muhtemel sebebi hastanemizin üçüncü basamak bir merkez olması nedeniyle çoğunluğunun kliniği daha ağır olan hemorajik inmeli hastaların hastanemize sevk edilmesine bağlı olduğunu düşünmekteyiz.

Çalışmamızda tüm yaş gruplarında BDH erkeklerde biraz daha fazla idi. BDH alt tiplerinin cinsiyetle ilişkisine bakıldığında ise İI ve SİH erkeklerde daha sık görülürken, SAK kadınlarda daha fazlaydı. Bununla beraber tüm inme alt tipleri için kadın-erkek arasındaki fark anlamlı değildi. Diğer yandan 45 yaş altı grupta hem kadınlarda, hem de erkeklerde en sik inme alt tipi SAK olup, 45-65 yaş arası grupta ise kadınlarda SİH ve SAK, erkeklerde ise III daha fazla idi. 65 yaş üstü grupta her iki cinste de anlamlı olarak III daha fazla bulundu. Böylece 65 yaş altı grupta hemorajik inmede kadınların sayısı erkeklerden biraz daha fazla olmakla birlikte ileri yaş gruplarında eşit olduğu ve sonuçta genel olarak tüm yaş grupları bakımından SïH'da cinsiyet tercihi olmadığı görülmektedir. Ege İnme Çalışması'na göre İI'lerde 40 yaş altı ve 75 yaş üstü hariç tüm yaş gruplarında erkeklerde daha belirgin inme sıklığı görülmektedir. Aynı çalışmada hemorajik inmelerin de 40 yaş altında ve 75 yaş üstünde erkeklerde daha fazla olduğu bildirilmektedir (Kumral ve ark., 1998).

Öteki BDH tiplerine göre SAK'nın oranının yaş ile daha az arttığı, bununla beraber en sık olarak 35-60 yaşları arasında görüldüğü ve insidansın ortalama 50 yaşta doruğa çıktığı bildirilmektedir (Özbenli, 2002). Çalışmamızda acile en sık başvuru ana yakınması bilinç kaybı (\% 45,7) olup bu hastaların büyük çoğunluğu da SİH'li hastalardı. Bazen taraf kas zaafı çok belirgin olmadığında, bu olguların acilde tanılarının gecikmesi olasılığına yol açabilir. Bu nedenle detaylı bir anamnez ve dikkatli nörolojik muayene tanı gecikmesi olasılığını azaltabilir. Çalışmamızda baş ağrısı ile başvuran hastaların \% 80'ini SAK'lı olgular oluşturdu. Bu sonuçlar, akut inmeli bir hastada sistemik ve ayrıntılı bir nörolojik bak1 ve anamnezin bize tanı alt grubu için ipucu sağlayabileceğini göstermektedir. Ege İnme Çalışması ile karşılaştırıldığında ilgili sonuçların bu çalışmamızdaki şikayet-tanı ilişkisi ile benzer olduğu görülmektedir (Kumral ve ark., 1998). İnmeli olguların \% 72-81'inde hipertansiyon öyküsüne rastlandığ ve akut inme geçiren hastaların \% 60-80'inde ilk başvuruda hipertansiyon saptandığı bildirilmektedir (Britton ve ark., 1986; Broderick ve ark., 1993; Fayad ve ark., 1998). Bizim çalışmamızda da hipertansiyon öyküsü risk faktörleri arasında en s1k olanı idi. Hipertansiyon öyküsü tüm inmeli hastalarımız için \% 65,1 olup, SİH'lı hastalar için \% 72,6 ile en yüksek idi. Oysa SAK tanısı alanların \% 48'inde hipertansiyon öyküsü vardı. İI'li olgularda ise bu oran \% 70,3 idi. Hipertansiyonun, laküner infarktlar için de en önemli risk faktörü olduğu ve vakaların ortalama \% 68'inde görüldüğü bildirilmektedir (John ve ark., 2000; Biler ve ark., 2004). Bizim çalışmamızda da laküner infarktta hipertansiyon öyküsüne hastaların \% 81,3'ünde rastlandı. Ege İnme Çalışması'nda hipertansiyon risk faktörüne İI'li hastaların \% 63'ünde, SİH'lı olguların \% 88 gibi oldukça yüksek bir oranında rastlanmış olup 
SAK tanısında \% 36 ile diğer tanı gruplarına göre daha düşük bir oranda olduğu ve tüm tanı gruplarında ise $\% 63$ olduğu bildirilmiştir (Kumral ve ark., 1998). Bu bulgular, çalışmamızdaki sonuçlarla benzerlik göstermektedir. Çalışmamızda hastaların \% 69'unun acile başvuru ve takip esnasinda iken hipertansiyonunun (TA>140/90 $\mathrm{mmHg}$ ) olduğu tespit edildi. Hipertansiyon $\% 83,8$ 'le en sik SIH tanı grubunda görülürken, bunu \% 60,9'la İİ ve \% 35,7 ile SAK tanı grubu izledi. Daha önceki çalışmalardan birinde SAK' da akut dönemde yaklaşık \% 50 olguda hipertansiyon tespit edilmiştir (Gürsoy, 2004). Çalışmamızda SİH tanı grubundaki ortalama tansiyon değerleri diğer tanı gruplarına göre istatistiksel anlamlı olarak daha yüksekti.

Çalışmamızda diyabet öyküsü hastaların \% 14,9'unda vardı. Çalışmalarda diyabetin, İ riskini 2-6 kat arttırdığı gösterilmiştir (John ve ark., 2000; Biler ve ark., 2004). Çalışmalarda, Asya Bölgesi'nde hipertansiyon ve diyabetin yüksek oranda bulunduğu ve ülkemizde yapılan çalışmalarla benzer sonuçlar taşıdığı görülmektedir (Kumral ve ark., 1998). Ege İnme Çalışması'nda hastaların \% 23'ünde diyabet öyküsü olduğu belirtilmiştir (Kumral ve ark., 1998).

Sigara içilmesinin inme riskini yaklaşık 2 kat artırdığ bildirilmektedir (Kumral ve ark., 1998; Biler ve ark., 2004; Çoban, 2004). Diğer bazı çalışmalarda ise sigaranın İI'nin yanında SAK' da da riski arttırdığı bulunmuştur (John ve ark., 2000; Biler ve ark., 2004; Çoban, 2004). Alkolizm öyküsü ve inme arasında ilişki olduğu bilinmektedir (Donahue ve ark., 1986). Örneğin sürekli ve fazla miktarda alkol tüketen kişilerde, hemorajik inmelerde en az üç kat artış olduğu tespit edilmiştir. Bizim çalışmamızda sigara içme öyküsü \% 13 ve alkol öyküsü \% 3,5 olup, SİH ve İI’li hastalarda alkol içme oranları benzerdi ve SAK grubunda alkol içen hasta yoktu. Bir çalışmada hemorajik inmenin aspirin alanlarda plasebo grubuna göre anlamlı olarak daha yüksek olduğu bildirilmiştir (Kase, 2004). Antikoagülasyona bağlı intraserebral hemoraji, tüm intraserebral hemorajilerin \% 10'unu oluşturmaktadır (Kase, 2004). Çalışmamızda oral antikoagülan kullanan 27 hasta vard 1 ve tanı gruplarına göre 13 hasta SİH, 10 hasta İI, 4 hasta SAK tanı grubunda idi.

Tüm İI'li hastaların en az \% 25'inde GİA anamnezi olduğu bildirilmektedir (Biler ve ark., 2004). Çalışmamızda GİA öyküsü olan hasta sayısının tüm İI'li hastaların \% 3,2'si idi. Ayrıca tüm olguların \% 21,7'sinde inme öyküsü vardı. İleri yaş grubunda, BDH, epileptik nöbetlerin en sık rastlanan nedenidir (Biler ve ark., 2004). Akut inmede epileptik nöbet görülme sıklığı ilk 14 gün içinde \% 2,5 ile \% 5,7 arasında değişen oranlarda bildirilmektedir (Biler ve ark., 2004). SAK'lı olguların \% 10'unda epileptik nöbet görülebildiği rapor edilmiştir (Özbenli, 2002; Çoban, 2004). Çalışmamızdaki değerler de daha önceki çalışmalarla uyumlu idi. Başvuruda epileptik nöbet geçirme oranları BDH alt gruplarından en sık SAK'da görülürken bunu İI ve SİH takip etti. Epileptik nöbet görülme oranı çalışmamıza göre hastaların \% 4,8'inde tespit edilmiş olup, olguların yarıdan çoğunu SAK tanı grubu oluşturdu (\% 10,6).

Ege İnme Çalışması'nda İI'li hastaların \% 23'ünde kalp hastalığı öyküsü gösterilmiştir (Kumral ve ark., 1998). Bizdeki kalp hastalığı oranı tüm olgularda \% 21,7 iken, İ tanı grubunda \% 39 idi. İnmeli hastaların \% 15-20'sinde AF saptandığı ve ileri yaş, hipertansiyon ve diyabet ile birlikte ise inme riskini daha da artırdığı bildirilmektedir (Utku ve ark., 2002). Çalışmamızda EKG çekilmiş olan hastaların \% 18,2'sinde AF vard1 ve III'li hastaları \% 37,5'inde tespit edildi. Akut BDH tanısı alan hastaların \% 26,1'i koma tablosunda idi. SİH tanı grubundaki hastaların \% 43,3'ünde GKS skoru 8 ve altında idi. İnme alt tiplerinde ortalama GKS skoru en düşük olan 9,2 ile SİH tanı grubu idi ve diğer gruplara göre bu fark anlamlı idi $(\mathrm{p}<0,05)$. En düşük GKS skoruna göre SİH'lı hastaları SAK'lı hastalar takip etti. Bir çalışmada SïH'da koma tablosunda olanların oranı $\% 35$ idi ve tanı grupları içinde en yüksek oran bu gruba aitti (Kumral ve ark., 1998). Çalışmalarda İİ olguları arasında en sık orta serebral arter (OSA) infarktları görüldüğü bildirilmektedir (Kumral ve ark., 1998; Biler ve ark., 2004). Ege İnme Çalışması'nda OSA infarkt oranı \% 56,9 ile en yüksek bulunmuştur. Çalışmamızda da OSA infarktı \% 64 ile en sık III subtipi idi. Ege İnme Çalışması'nda İI'li hastaların \% 69'unun karotis sistemde, \% 27'sinin vertebrobaziller sisteme ait olduğu bildirilmektedir (Kumral ve ark., 1998). Çalışmamızda karotis sistem infarktlarının oranı \% 82 bulundu.

Klinik, BBT ve beyin-omurilik sıvısı (BOS) sonucunda SAK tanısı konan hastalarımızın \% 96,5'inde anevrizma ve $\% 3,5$ 'inde de arteriovenöz malformasyon tespit edildi. Hastalarımızın \% 26,7'sinde hiponatremi mevcut olup SAK tan 1 grubunda \% 30,7 oranı ile en fazla idi. Hastaneye yatırılan hastalar arasında hiponatremik olanlarda ölüm oranı, olmayanlara göre 60 kat daha fazla olduğu bildirilmektedir (Yerliyurt, 2003). Hiponatremi sonucu artmış serebral ödem ve iskemi nedeniyle nörolojik semptomların şiddetinde artma olabilmektedir (Betjes, 2002). Wijdicks ve ark. (1985) SAK geçiren hastalarda yaptığı çalışmada hastaların \% 32,8'inde hiponatremi saptamışlardır. Hiperglisemi, akut inmelerde laktik asit formasyonunu artırır, $\mathrm{pH}$ ' 1 düşürür ve metabolitlerin birikimini artırarak iskemik alanın büyümesine yol açar. Bu nedenlerle, akut inme sonrası kan şekerinin kontrol altına alınması ve 100-150 mg/dL civarında tutulması önerilmektedir (Baird ve ark., 2003; Pasero ve ark., 2003; Song ve ark., 2003). Çalışmamızda hiperglisemi görülme oranı \% 69,1 idi. Bu sonuçlar akut inmeli olguların AS'te kan şekerlerinin erken regülasyonunun çok önemli olduğunu göstermektedir. Bamford ve ark. (1991) yaptığ bir çalışmada akut dönemde hemorajik inmeli hastalarda olan ölüm oranının III'li hastalara göre daha fazla olduğunu ortaya koymuştur. Akut dönemdeki ölüm oranları nörolojik komplikasyonlara, uzun dönemdeki ölüm oranları ise medikal komplikasyonlara bağlanmıştır. $\mathrm{Bu}$ nedenle akut dönemde olabilecek komplikasyonlar karşısında uyanık olmak ve yeterli önlemlerin alınması gerekmektedir. Bu sonuçlarla bizim çalışmamızdaki sonuçlar karşılaştırıldığında, acilde geliş anında veya gözlem altında iken ölen hastaların dağılımı incelendiğinde 25 hastanın 19 tanesi hemorajik inme, 6 tanesi de III idi.

Son y1llarda, akut İI'de trombolitik ve nöroprotektif ilaçlardaki yenilikler, yakın zamanda, erken dönemde inmeye bağlı ölümlerin ve sakatlıkların azaltılacağı konusundaki ümitleri artırmaktadır. Akut Iİ'li hastalarda hastaneye erken başvurunun (özellikle ilk 3 saat) trombolitik tedavi yönünden önemli olduğu bilinmektedir (Schellinger ve ark., 2004). Amerika Birleşik Devletleri’nde yapılan bir çalışmada, 24 saat içinde hastaların ancak \% 42'sinin hastaneye ulaşabildiği görülürken, İsveç’te hastaların \% 43'ü 6 saat içinde hastaneye ulaşmaktadır (Asplund ve ark., 1994). Ülkemizde yapılan bir çalışmada akut inmeli olgularda hastane öncesi gecikme süresi 
ortalama 92,7 dakika olarak bildirilmiştir (Keskin ve ark., 2005). Bu çalışmada inmeli olgularda belirtilerin başlaması ile hastaneye getiriliş süresi ilk 3 saat içinde olanların oranı $\% 49$ olarak verilmektedir. Yazarlar inmeli olgularda hastane öncesi dönemde gecikmeye neden olan en önemli sürecin, medikal yardımı isteme süresinin olduğunu belirtmektedirler. Çalışmamızda ilk 3 saat içinde hastaneye başvuranların oranı \% 20,7 idi. Çalışmamızda elde edilen sonuçlara bakıldığında daha önceki çalışmalarla büyük paralellikler göstermesine rağmen, bazı farklılıkların da olduğu görülmüştür. Ülkemizdeki akut BDH'nın epidemiyolojisini araştırmak için daha fazla prospektif kontrollü çalışmaların yapılması gerektiği açıktır. Ama en önemli sorun trombolitik tedavi için altın pencere dönemi olan ilk 3 saat içinde merkezimize ulaştırılan hastaların oranının azlığıdır. Böylece, yapılan bu ve diğer benzeri çalışmalarla bu hedeflerin yakalanacağını ümit etmekteyiz.

\section{KAYNAKLAR}

Altıntop, L., Güven, H., Doğanay, Z., Aygün, D., Sünter, T., Deniz, T., Yerliyurt, M., Şahin, H., Karaduman, A., Duran, L., 2001. Ondokuz May1s Üniversitesi Tıp Fakültesi Acil poliklinik çalışmalarının değerlendirilmesi. O.M.Ü. Tıp Dergisi. 18, 19-26.

Asplund, K., Wester, P.O., 1994. Stroke management around the world-Sweden. Cerebrovasc. Dis. 4, 432-434.

Baird, T.A., Parsons, M.W., Phanh, T., 2003. Persistent poststroke hyperglycemia is independently associated with infarct expansion and worse clinical outcome. Stroke. 34, 2208-2214.

Bamford, J., Sandercock, P., Dennis, M., Burn, J., Warlow, C., 1991. Classification and natural history of clinical subtypes of cerebral infarction. Lancet. 337, 1521-1526.

Betjes, M.G.H., 2002. Hyponatremia in acute brain disease: The cerebral salt wasting sendrom: A review. New Eng. J. Med. 13, 9-14.

Biler, J., Love, B.B., 2004. Ischemic cerebrovascular disease. In: Bradley, W.G., Durolf, R.B., Fenichel, G.M., Jankoviç, J. Neurolgy in clinical practica. Philadelphia; Butterwohk and Heinemann. 1197-1249.

Britton, M., Carlsson, A., de Faire, U., 1986. Blood pressure course in patients with acute stroke and matched controls. Stroke. $17,861-864$.

Bogousslavsky, J., van Mele, G., Regli, F., 1988. The Lausanne stroke registry: Analiysis of 1000 consecutive patients with first stroke. Stroke. 19, 1083-1092.

Broderick, J., Brott, T., Barsan, W., 1993. Blood pressure during the first minutes of focal cerebral ischemia. Ann. Emerg. Med. 22, $1438-1443$.

Çoban, O., 2004. Beyin damar hastalıklarında tanımlar, sınıflama, epidemiyoloji ve risk faktörleri. Öge AE. Nöroloji. Nobel Tıp Kitabevleri. İstanbul. 193-197.

Donahue, R.P., Abbott, R.D., Reed, D.M., 1986. Alcohol and hemorrhagic stroke: The Honolulu heart program. JAMA. 255, $2311-2314$.

Fayad, P.B., Awad, I.A., Easton, J.D., 1998. Surgery for intracerebral hemorrhage. Neurology. 51, 69-73.

Gürsoy, G., 2004. Beyin kanaması. Oge AE. Nöroloji. Nobel Tip Kitabevleri. İstanbul. 229-248.

John, C., Brust, M., 2000. Cerebral infarction. In: Rowland LP. Merrit's Neurology. Lippincott Williams and Wilkins; Philadelphia. $232-240$.

Kase, C.S., 2004. Intracerebral hemorrhage. In: Bradley, W.G., Durolf, R.B., Fenichel, G.M., Jankoviç, J. Neurolgy in clinical practica. Philadelphia; Butterwohk and Heinemann. 1251-1267.

Keskin, Ö, Kalemoğlu, M., Ulusoy, E., Uzun, H., Yıldırım, I., 2005. Akut inmeli olgularda hastane öncesi geçikme nedenlerinin irdelenmesi. Nobel Med. 1, 14-17.

Kumral, E., Özkaya, B., Sağduyu, A., 1998. The Ege stroke registry: A hospital-based study in the Aegan Region, Izmir, Turkey. Cerebrovasc. Dis. 8, 278-288.

Özbenli, T., 2002. Subaraknoid kanama. Balkan, S. Serebrovasküler Hastalıklar. Ankara. Güneş Kitabevi. 166-183.

Pasero, S., Ciacci, G., Ulivelli, M., 2003. The influence of diabetes and hyperglycemia on clinical course after intracerebral hemorrhage. Neurology. 61, 1351-1356.

Schellinger, P.D., Kaste, M., Hacke, W., 2004. An update on thrombolytic therapy for acute stroke. Curr. Opin. Neurol. $17,69-77$.

Song, E-C., Chu, K., Jeong, S-W., 2003. Hyperglycemia exacerbates brain edema and perihematomal cell death after intracerebral hemorrhage. Stroke. 34, 2215-2220.

Utku, U., Çelik, Y., 2002. Strokta etyoloji, sınıflandırma ve risk faktörleri. Balkan S. Serebrovasküler hastalıklar. Güneş Kitabevi. Ankara. 4961.

WHO Guidelines Subcommitte., 1999. World health organization international society of hypertension guidelines for the management of hypertension. J. Hypertens. 17, 151-183.

Wijdicks, E.F.M., Vermeulen, M., Hijdra, A., van Gijn, J., 1985. Hyponatremia and cerebral infarction in patients with ruptured intracranial aneurysms: Is fluid restriction harmful? Ann. Neurol. 17, 137-140.

Yerliyurt, M., 2003. Erişkinlerin akut santral sinir sistemi hastalıklarında hiponatremi. Uzmanlık tezi. Ondokuz Mayıs Üniversitesi, Tıp Fakültesi, Acil Tip Anabilim Dalı, Samsun. 